Article

\title{
Distributional Challenges of Sustainability Policies-The Case of the German Energy Transition
}

\author{
Erik Gawel ${ }^{1,2, *}$, Klaas Korte ${ }^{1}$ and Kerstin Tews ${ }^{3}$
}

Received: 30 September 2015; Accepted: 10 December 2015; Published: 16 December 2015

Academic Editor: Richard Matthew

1 Department of Economics, Helmholtz Centre for Environmental Research-UFZ, Permoserstr. 15, 04318 Leipzig, Germany; klaas.korte@ufz.de

2 Institute of Infrastructure and Resources Management, University of Leipzig, Grimmaische Straße 12, 04109 Leipzig, Germany

3 Environmental Policy Research Centre (FFU), Freie Universität Berlin, Ihnestraße 22, 14195 Berlin, Germany; kerstin.tews@fu-berlin.de

* Correspondence: erik.gawel@ufz.de; Tel.: +49-341-235-1940; Fax: +49-341-235-451940

\begin{abstract}
Sustainability policies based on the economic rationale of providing incentives to get prices right inevitably place a significant burden on society and often raise distributional concerns. The social acceptability of Germany's energy transition towards more sustainable generation and usage of energy is frequently the subject of such critical appraisals. The discourse centres upon the burden imposed on electricity users as a result of the promotion of renewable energy sources in the electricity sector in accordance with the German Renewable Energy Sources Act (EEG). A regressive EEG surcharge is suspected of driving up energy prices unreasonably and of being socially unjust. It is also argued that high-income utility owners profit from the EEG system at the expense of low-income electricity consumers (redistribution from bottom to top). The aim of this paper is to examine the validity of these two hypotheses and to show that both exhibit substantial theoretical and empirical weaknesses, with climate and environmental policy being played off against social policy in a questionable manner. At the same time, the article points out remaining conflicts between energy policy and social policy and makes corresponding policy recommendations for their resolution, thus contributing to reconciling distributional concerns arising in the context of incentive-oriented sustainability governance.
\end{abstract}

Keywords: sustainability trade-offs; renewable energies; social compatibility; distributional effects; environmental policy; equity

\section{Sustainability Policy and Social Acceptability}

Over the past few decades, sustainability has emerged as one of the central guiding principles of policy formulation, especially - but not exclusively-in the field of environmental, climate and development policy. According to the three-pillar model, sustainable development is to be achieved on three levels: ecological, social and economic. The United Nations recently reaffirmed this triad of targets in its Sustainable Development Goals, which define the direction to be taken in the formulation of global policy up to 2030 and have been adopted at the United Nations Summit in New York at the end of September 2015 [1]. As explicitly emphasised in that context, the three dimensions of sustainability (economic, social and environmental) are to be pursued "in a balanced and integrated manner" [1] (p. 3). The simultaneous pursuit of all three dimensions of sustainability inevitably involves trade-offs which decision makers have to take into account and address when selecting policy instruments. 
As long as sustainable environmental and climate policy adheres to the polluter-pays principle in the design of policy instruments and consequently strives to internalise or avoid negative environmental externalities in the production of goods on the polluter's side, it will regularly be accompanied by (desired) increases in the costs of production of goods which damage the environment or the climate, respectively. If the demand-side response to price changes is not completely elastic, then there will be a subsequent increase in consumer prices for goods that have been produced in an unsustainable manner. This demonstrates very clearly that polluter-oriented environmental and climate policy is also accompanied by new distributional effects and frequently results in rising commodity prices for consumers. When this affects basic commodities that are consumed to a similar extent by consumers in the different income groups, such as water or electricity, the burden is typically felt relatively more in the lower income groups than in the higher income groups. Against this background, sustainability policies that lead to rising consumer prices are often classified as socially unjust because they would impose a disproportionately large burden of the sustainability policy costs on low-income households (see in general: [2,3]; for water: [4]; for energy: [5]). However, such a perspective considers prices only in terms of their distributional effect and disregards their allocative purpose. Moreover, with a view to a fair distribution of the burden, critics have focused solely on the ability-to-pay principle. Their evaluation of fairness is based entirely on the yardstick of distributive justice (iustitia distributiva), and not on the yardstick of commutative justice (iustitia commutativa). Thus, the extent to which this approach can actually take the different sustainability goals into consideration in a way that could be described as "balanced" in the above sense seems questionable. However, in this article, we want to check the validity of this criticism of price increasing sustainability policies and, thus, we will generally follow the critics in their understanding of social justice (or fairness or equity which we will regard and use as synonyms for the purpose of this paper) as being only reliant on vertical income distribution. Nevertheless, we keep in mind that there are other dimensions of justice, meaning that a policy that disregards the ability-to-pay principle is not per se unfair, and we will point out this one-dimensionality of argumentation in this article.

In Germany, a very intense discussion on the social acceptability of environmental and climate policy has taken place in recent years in connection with the so-called Energiewende (energy transition). The United Nations also attaches particular importance to the sustainable development of energy supply as one of 17 explicitly named sustainable development goals. The aim is to ensure "universal access to affordable, reliable and modern energy services" [1] (p. 16) while at the same time significantly increasing the share of renewable energy sources and energy efficiency [1]. Germany's energy policy is pursuing very similar aims as laid down in the German Energy Act (Energiewirtschaftsgesetz), which was adopted to promote an affordable, reliable and environmentally sound supply of electricity, while at the same time, with the German Federal Government's energy concept of September 2010 [6], setting ambitious targets for the future share of renewable energies and the reduction of energy consumption. However, the instrument used in this context to promote renewable energy sources-the Renewable Energy Sources Act (EEG) - has been exposed to continuous criticism, particularly for its alleged social injustice. The debate centres above all on high energy prices which are said to be caused by the EEG and which should be avoided in the interests of social justice [7-10]. This debate is therefore well suited for analysing the extent to which the allegation of social injustice of sustainability policy based on the polluter-pays principle is justified, and whether the resulting demand to refrain from deploying price-driving policy instruments in the area of basic commodities can be seen as an adequate response.

For this purpose, the present paper begins by taking a closer look at two of the most heavily criticised distribution questions encountered in German renewable energy support policy: in both cases, the promotion of renewable energies under the Renewable Energy Sources Act (EEG), the centrepiece, so to speak, of Germany's energy transition governance, is criticised as being socially unjust. Thesis 1 claims that the EEG support scheme is a major driver of energy prices and, as such, is socially unjust (Section 2.1). Thesis 2 furthermore claims that it is "the rich" who profit primarily, if not exclusively, from the EEG support scheme and that the EEG therefore represents a powerful instrument 
for redistribution from the bottom to the top (Section 2.2). Even though it can be demonstrated that this critique is not convincing and at least does not provide any grounds to weigh up climate, environmental and energy policy against social and distributional policy concerns (Section 2), the question remains as to what extent energy transition policy also has to address the distributional effects of high energy prices (Section 3). The third section describes how policy instruments that can adequately address potential distributional problems associated with the renewable energies support scheme while being compatible with energy policy could be shaped. In Section 4, we locate the issue of this paper in the international discourse and discuss why the debate on social acceptability of renewables support seems to be extraordinarily intense in Germany. The paper closes with a conclusion (Section 5).

\section{The Social Acceptability of Energy-Related Sustainability Policies: Is Germany's Renewable Energies Support Policy Socially Unjust?}

\subsection{The RES Support Scheme as a Driver of Energy Prices_Problematic on Social Grounds?}

\subsubsection{Overview}

The debate on the suitability of the EEG support mechanism for the expansion of renewable energies also regularly addresses the personal distributional effects of the EEG surcharge on different household types. The EEG surcharge is added to the price of electricity-according to the market result of passing on the burden attributed to energy utilities-and serves to cover the additional costs of promoting electricity generated from renewable energy sources. Its total volume is calculated as the annual difference between the statutory remuneration for the power generated from renewable energy sources and being fed into the grid and (since 2010) the revenue from its sale on the energy exchange. To refinance this difference, the burden of the EEG surcharge is distributed to differing degrees among the various consumer groups, whereby non-privileged consumer groups such as private households bear the highest economic burden [11]. This consumer group has seen a sharp surcharge increase between 2010 and 2014 (see Figure 1). The debate on the social acceptability of the renewable energies support scheme in Germany, which has been smouldering for several years and continues to this day, centres on the amount of this surcharge.

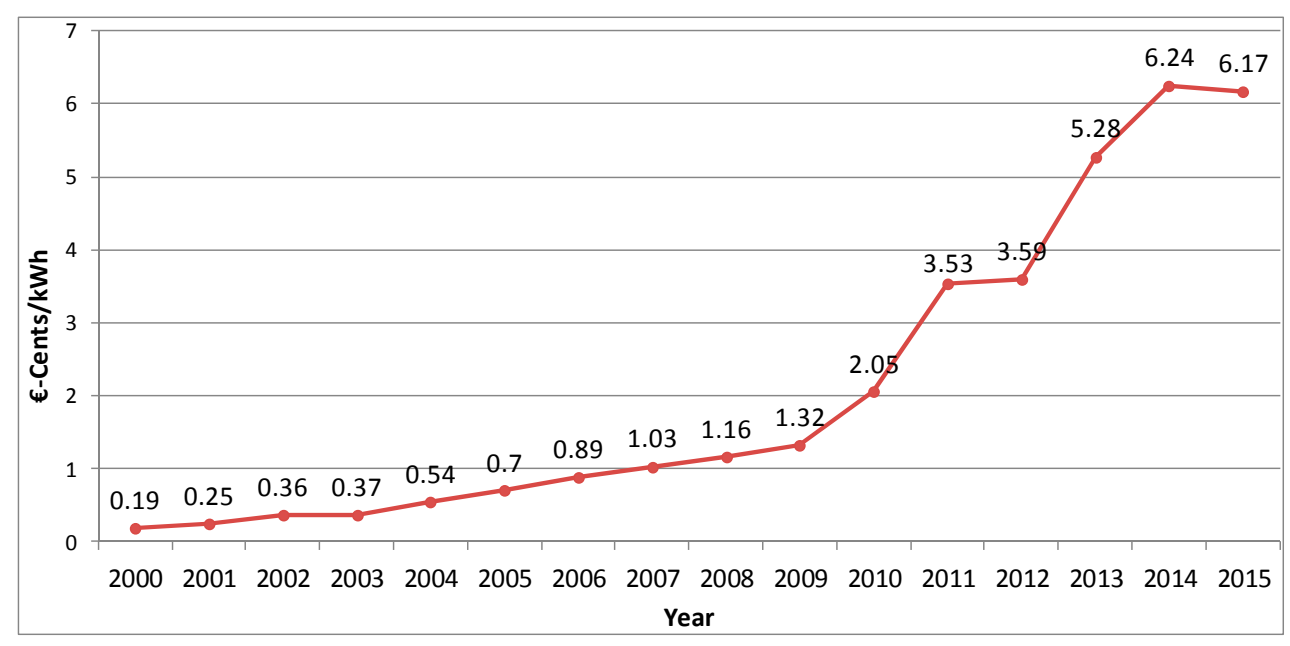

Figure 1. Surcharge for renewables support according to the German Renewable Energy Sources Act (EEG surcharge) for private households 2000-2015 (in Euro-cents per kilowatt hour). Source: Authors' own graph (data sourced from [12]).

In this context, interest groups in the political sphere, in particular, but also to some extent in academic circles (see, instead of many, [7]), have put forward a line of argument claiming that the EEG surcharge is responsible for significantly and, at the same time, unjustifiably driving up energy prices, 
thus burdening lower income households in particular, and for that reason it appears problematic from a social policy perspective. However, this frequently advanced line of argument does not stand up to closer scrutiny.

A comparison of the price development of the different household energy carriers (electricity, gas, heating oil, petrol) in Germany since the liberalisation of the electricity market in 1998 shows that prices for all energy carriers have increased significantly since then and by far the most moderate price increase was for electricity [13]. As a consequence, electricity spending as a share of the total energy costs of an average household has been declining (Figure 2). Remarkably, nevertheless, price increases for other sources of household energy have not been discussed and criticised to the same extent, especially not with respect to their personal distributional effects [14]. As a result of the marked decline in global crude oil prices since mid-2014, prices and, ceteris paribus, also expenditures on petrol and heating oil have dropped significantly and are presently at the level of 2009. However, even in 2012 when the price for crude oil was at its highest, the debate about the social acceptability of energy prices in Germany focused exclusively on the price of electricity. This clearly demonstrates that in the public's perception, and evidently also to some extent in academia's perception, such price increases, which are the consequence of state intervention in the market, are evaluated differently to price increases caused by the market. This is despite the fact that the effects on consumer spending are the same and that an allocation of external environmental costs (that in fact is meant to increase public welfare) can only be organised by the state, meaning that there is no private sector alternative. Rather, the decisive question here is whether or not the state intervention can be considered welfare-increasing (which is out of scope of this paper). Personal distribution impacts do not suffer from a particular lack of justification in case they are triggered by allocation-oriented sustainability policies (instead of pure market-driven impacts).

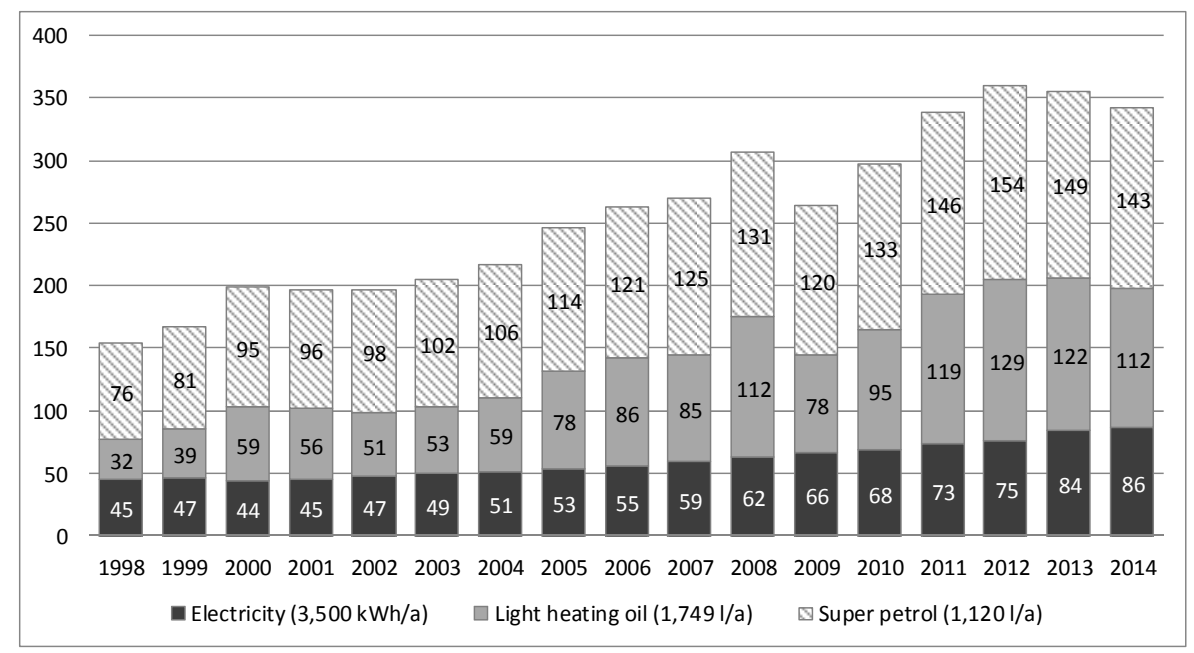

Figure 2. Average monthly expenditures of a typical three-person household on energy consumption. Source: Authors' own graph (price data sourced from [15], average consumption data according to the Renewable Energies Agency [16]).

However, the strong governmental regulation of electricity prices makes them appear "politically negotiable" and makes them attractive for rent-seeking activities by interest groups. It serves as an invitation to political "negotiations" about the administered price components, while those price components that are contingent on the anonymous market (e.g., global crude oil prices) escape such influence. 


\subsubsection{The Impact of the Promotion of Renewable Energy Sources on the Price of Electricity}

Against the background of the bemoaned social unacceptability of a sustainability policy in the form of support for renewable energies by means of the EEG, the first question that arises is what role does the EEG support scheme actually play in the electricity price increases observed? The frequent use of the EEG surcharge as a yardstick for the EEG-induced increases in the price of electricity is, however, totally insufficient for that purpose. This is because, as a differential amount between the feed-in tariffs paid and the market value of the EEG-supported electricity on the electricity exchange, the surcharge not only depends on the extent of the support for renewables, but also on price developments in the electricity market. The latter is in turn influenced by the input of renewables, which tends to have a lowering effect on trading prices for electricity. Because intermittent renewables such as wind and photovoltaics are offered on the spot market at almost null marginal costs, this leads to the more expensive price-setting marginal power plants being squeezed out, so that the price for electricity on the electricity trading market falls, at least temporarily, as a result of renewables being fed into the grid system - and thus also the market value of the renewables being fed in (cf. e.g., [17]). This situation is described as the merit order effect and, due to the surcharge mechanism, the result is that the EEG surcharge, ceteris paribus, must increase, although not necessarily (in equal measure) does the final consumer price increase (see about the extent of the merit order effect in Germany e.g., [18,19]; for a good overview study on the merit order effect and relevant influencing factors, see also [20]).

As a result of the merit order effect, therefore, the reference price per kilowatt-hour of electricity does not increase in equal measure to the EEG surcharge. As modelling studies by the Forum Green Budget Germany (Forum ökologisch-soziale Marktwirtschaft) show, the merit order effect significantly lessens the price-driving effect of the EEG surcharge. The contribution of the EEG to the electricity price increases of recent years is thus much lower than the EEG surcharge itself would suggest [13].

What is more, the observed electricity price increases caused by the EEG surcharge can only be partly attributed to the actual financial promotion of renewables. The reasons for this are twofold: First, a legislative change to the equalisation mechanism in 2010 is responsible for a large part of the subsequent increase in the EEG surcharge. Up to 2009, the quantities of electricity remunerated under the EEG were passed on in the accounts of the electricity suppliers in such a way that all of them show an equally large share of EEG electricity in their energy mix. For electricity quantities received in accordance with this "physical roll-over", the electricity suppliers had to pay an average EEG tariff which was determined on a monthly basis. This meant that there was no trading of EEG electricity on the energy exchange. Since 2010, EEG power is traded on the energy exchange's spot market by the transmission system operators (TSOs), and the remaining additional costs are passed on to the final consumer via a fixed EEG surcharge that applies nationwide. The above-mentioned merit order effect has consequently been in effect since then. As a result, revenues from the sale of EEG-remunerated electricity in 2014 amounted to only about half of revenues from the sale EEG electricity in 2009 [11], despite the fact that the capacity generated by EEG installations has almost doubled in the same period [21]. The differential costs that have to be covered by the EEG surcharge have also risen correspondingly so that the EEG surcharge has had to be increased. Second, the fact that electricity-intensive industries are exempted from paying the surcharge drives up the surcharge for private households to a significant extent $[11,22]$ : While companies that are privileged in this way contribute only partially, or in some cases practically not at all, to the promotion of renewables, as industrial customers they mainly benefit to the full extent from falling electricity trading prices as a result of the merit order effect, so that on balance they possibly even gain a significant advantage from the EEG surcharge mechanism [18]. This takes place, of course, at the expense of non-privileged final consumers (e.g., private households) because the EEG surcharge they are required to pay must be set at an amount high enough to cover the differential costs. In 2014, the share of the EEG surcharge for refinancing the exemption from the surcharge of privileged final consumers amounted to 1.35 cents per $\mathrm{kWh}$ or approximately $22 \%$ [11]. In contrast, the share of the actual costs of supporting the construction of new EEG installations in the EEG surcharge increase for 2014 was only very small. Estimates of the 
German Renewable Energy Federation go so far as to assume a share of only about 15\% of the increase in the EEG surcharge [17]. In addition to this, the surcharge that de jure the electricity suppliers are required to pay has the effect of a quantity tax and can only be correspondingly passed on according to the price elasticity of supply and demand on the market. This is because the statutory equalisation mechanism of the EEG ends with the power supply company (§60 (1) EEG) or with the final consumer,

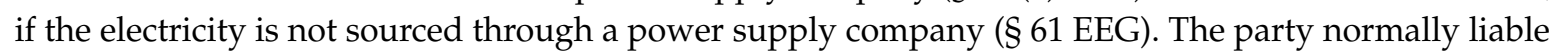
to pay the EEG surcharge is therefore initially the power supply company. However, depending on price elasticity, those power supply companies will only be able to partially pass on the surcharge to their final consumers because these might respond to rising prices with a fall in demand. The result is that a full transfer of the surcharge is profit-reducing for the power supply company and, hence, part of the EEG surcharge cannot be passed on to the final consumers. How high the respective share borne by the final consumers and the power supply companies is, i.e., how the burden of the EEG surcharge is distributed, depends on the relationship between the price elasticity of supply and demand. The more elastic one side of the market is in response to the other, the lower its share of the tax will be (cf. e.g., [23]). Therefore, the question of who bears the economic burden of the surcharge de facto is determined by a market outcome, which consumers can influence by means of their price elasticity. Not least for that reason, the development of industrial electricity prices is much more moderate than electricity prices in the household consumer segment.

Thus, it may be concluded that the promotion of the renewables via the EEG does in fact contribute to a certain extent to an increase in electricity prices. Nevertheless, contrary to frequent assertions, its contribution is significantly smaller than reflected by the amount of the EEG surcharge. For instance, the remuneration payments for EEG installations roughly doubled in the period from 2009 to 2014, whereas the EEG surcharge has more than quadrupled in the same period [11]. Furthermore, other important power price drivers have to be taken into account.

\subsubsection{Personal Distribution Impacts of Electricity Price Increases}

However, the observation of a price increase alone does not allow one to draw any definitive conclusions about its distributive justice. Allegations by critics that the EEG surcharge is supposedly unjust are attributed to the fact that the income elasticity of demand for energy is very low, so that the share of spending on electricity as a percentage of total consumer spending increases with decreasing household income $[5,7,24]$. In addition, due to the low price elasticity of demand, rising electricity prices lead, ceteris paribus, to an amplification of this regression effect [25]. And, indeed, in recent years the share of household income spent on electricity has risen more strongly in the lower-income groups than in the higher-income groups [26]. Critics of the EEG see this situation as problematic in terms of personal distribution and, against this backdrop, regard the EEG as an example of poorly designed distribution policy (cf. e.g., [8,9]). Despite this relatively stronger increase, the extent of the burden remains for the most part moderate, even in Germany's lower-income groups, as shown in empirical studies [24,27].

Although it is true that electricity price increases resulting from an increasing EEG surcharge always lead to a relatively heavier burden on low-income households, this also applies to the same extent to electricity price increases that have quite different causes [28]. Indeed, it applies to electricity per se: its costs, like the acquisition costs for all other basic commodities, also have a regressive effect. However, in the current debate it is often only the distributional effects of the EEG surcharge itself that are seen as problematic, whereas market-driven energy price increases or the general regressive effects of other basic commodities (such as water) are not.

At the same time, EEG-induced energy price increases are not a state-prescribed "stroke of fate" to which electricity consumers, and in particular the more vulnerable in society, are defencelessly exposed: The fact that it is not prices but costs (as a product of price and quantity) that can have a burdening effect and that consumers, as market participants and decision-makers, also have opportunities to influence both the market price (by changing their supplier) as well as the quantity (consumption choices) is 
often overlooked in the process. Irrespective of income situation, it is generally possible to respond to rising prices by lowering consumption and by switching to a different tariff and/or supplier in order to stabilise spending. Of course, in certain cases these options may be limited. For instance, it is argued that (1) a change of tariff is often not feasible for low-income households, that (2) due to the low price elasticity of the demand for electricity, there is hardly any savings potential in these households and/or that (3) budget restrictions prohibit the exploitation of such potential.

Regarding point (1): From an economic perspective, switching to a different supplier in a competitive market is an adequate consumer response to rising prices. However, for some (often poorer) households, this can be problematic as negative credit reports from credit rating agencies can prevent them from entering into a contractual relationship with a different supplier. However, this is thought to affect only a fraction of households in the lower-income segments. Furthermore, those who are in a position to switch supplier should use this opportunity not only in their own interests but also in the interests of the greater good because, by doing so, they promote competition between suppliers. This also puts competitive pressure on suppliers of basic supply tariffs, thus resulting in lower prices. Not least due to the lack of switching activity, providers of basic supply tariffs have in recent years succeeded in increasing their margins significantly vis-à-vis the providers of competitive tariffs [29].

Regarding point (2): To deduce a lack of savings potential from a low price elasticity of the demand for electricity in private households is also not entirely convincing: As a local measure, elasticity of demand merely indicates that, at the present price level, the response to price changes will only be proportionately lower (this does not necessarily mean "low") quantity adjustments. However, one cannot directly conclude from this that the energy efficiency potential of consumers is already exhausted or unaffordable due to budget restrictions. This is because there are many possible reasons for a low elasticity of demand at the present price level: in particular, the disutility of reducing power consumption can be estimated higher in relation to the benefit of the savings on energy spending so that efficiency potential will only be exploited at higher prices.

Regarding point (3): Several studies have shown that German households have substantial potential for saving energy costs by replacing inefficient household appliances or so-called "white goods" [30]. Because of the high acquisition costs of these goods, low-income households can indeed face budget restrictions in this area. In the area of energy efficiency, state support could possibly be beneficial and help to achieve energy transition targets and, from an economic perspective, it is at any rate preferable to electricity price interventions, which are often called for on social grounds [31,32]. State measures should only be taken to address any remaining affordability and implementation problems after exhausting the potential offered by appropriate changes in behaviour, both in terms of switching supplier and altering consumption.

Finally, the distributional aspect of electricity prices is oftentimes the sole subject of scrutiny in the debate, unlike their economic allocation function, which is ignored entirely. Yet, it is precisely this function that plays a prominent role in the German energy transition policy [33,34]. Because another essential-albeit politically neglected-target of the German as well as the international energy transition is the absolute reduction of electricity consumption [1,35]. As long as price-driving environmental policy instruments contribute to reflecting true costs in the prices, they have a steering effect and an important macroeconomic function. In addition to the EEG surcharge, which in this respect serves as an energy tax on the measured energy consumption, the European emissions trading system or the German electricity tax can also be counted among these instruments.

\subsubsection{What Do Prices Say about Justice?}

Irrespective of the actual distributional effect of EEG-induced electricity price changes, one must ask to what extent the electricity price is at all useful for drawing conclusions about the fairness of the personal distribution of electricity generation costs. Apart from the fact that ideas about a "fair" distribution of the burden of the costs of electricity generation are likely to differ, the price of electricity itself appears completely unsuitable as a measure of justice given that the current electricity prices only 
insufficiently reflect the true costs of supplying energy. The impact of state subsidisation-especially of conventional electricity generation - and insufficient internalisation of the external costs of electricity generation is that electricity generation incurs costs which are not reflected in the electricity price, but which nevertheless appear elsewhere, for example as burdens on public budgets or utility losses on the side of those affected by the externalities. Those subsidies and external costs are likewise associated with personal distributional effects which, however, are far less transparent than the distributional effects of a concrete levy on the electricity price. For example, a study conducted by the Forum Green Budget Germany estimated the total hidden funding value for conventional energies and, using the currently valid EEG equalisation mechanism, arrived at a theoretical "conventional energies surcharge" of approximately 10 Euro-cents per $\mathrm{kWh}$ [36]. Such calculations are of course based on far-reaching assumptions and estimates, particularly when it comes to the external costs of conventional electricity generation. However, this type of approach is unavoidable when accounting for intangible and intransparent cost and funding percentages, and, at the same time, fundamentally necessary for a fair comparison of macroeconomic costs, even though the underlying methodological and data problems are not likely to allow reliable predictions.

Against this background, narrowing down the focus to electricity prices should be viewed extremely critically, as it neglects to take into account the distribution of the costs associated with the supply of electricity elsewhere. In addition, the distribution of the costs of conventional electricity generation is heavily influenced by the EEG support scheme (avoidance of external costs by substituting conventional generation, and in particular reduction of the costs of climate change as a result of lower greenhouse gas emissions, avoided subsidisation of conventional forms of generation). Focussing on the EEG surcharge also neglects to take this into account.

Nonetheless, in view of the purported social imbalance of promoting renewables on the basis of electricity prices, critics have time and again called for renewables support to be provided through other, allegedly more equitable financing channels; in particular, financing via public budgets is frequently favoured here (cf. e.g., [10,37-39]). Alongside calls for tax-based funding of the promotion of renewables on the grounds of distribution, constitutional concerns about the EEG surcharge have in some cases also led to such demands (cf. e.g., [37], for a critical review see [40-42]). But that financing channel is not "distribution neutral" either, rather it is accompanied by its own new, less transparent distributional effects. After all, refinancing will inevitably be required, and this can take place in three ways: (1) through tax increases or the introduction of new taxes, (2) at the expense of other expenditure items in the state budget or (3) via new public debt. On the grounds of fairness, the advocates of tax-based support for renewables usually still owe an explanation as to which of these financing options should be used, which new personal distributional effects would result, and why it should be more "just" than the EEG financing scheme. From a public finance perspective, however, the differential incidence between two measures being compared always has to be taken into consideration; only then can robust statements about the "relative" distributional effects of a specific form of financing be derived.

\subsection{Do Only "the Rich" Benefit from RES Support?}

A second point of criticism frequently raised in the EEG debate over distribution is that the financing of the surcharge on the basis of the EEG causes vertical distribution effects at the expense of socially disadvantaged groups as a result of the induced expenditure flows from electricity consumers to producers. While homeowners profit from the promotion of photovoltaics, less well-off tenant households have to pay the surcharge on the electricity price. The EEG is therefore seen as a state-organised-although also unintended-instrument of redistribution with considerable volumes [43]. In this context, it has even been described as "the greatest social redistribution from the bottom to the top ever initiated with the help of a social-democratic government" [44].

First, an element of this critique is that only "the rich" (more precisely: capitalists investing in renewable energy technologies that qualify for support) can receive guaranteed feed-in tariffs 
under the EEG support scheme [26]. This point is undoubtedly correct-at any rate, it is true that with increasing capital assets greater use can and is made of this option $[5,25]$. However, in this characteristic, capital investment in installations for generating renewable energies does not differ from any other capital investment, and that includes investments in conventional energy generation plants. It goes without saying that capital investments can only be made by those who own capital and that only they can achieve a return on that capital. All non-state supply of energy requires the investment of private capital, and this applies just as much to the supply of renewable energy. Even in the era of conventional energy generation, homeowners who owned capital also possessed shares in energy companies and benefitted from a return on their capital investment (which had to be borne by electricity consumers). Now, in the era of renewables, the investor himself becomes a producer and, all at once, the economic process itself appears no longer justifiable. The fact that electricity prices and the returns on investments in electricity generation are subject to state influence is not unique to the era of renewables either (regional monopoly rents, tax relief, etc.). On that front, it is not clear why a different benchmark should apply to EEG-supported plants nor has this question been clarified by the critics. The EEG is a state instrument for stimulating the transformation of energy generation and not an instrument for balancing out different financial circumstances among the population. Fundamental injustices in society should be resolved through a different political route with respect to social policy rather than through environmental policy [28].

Following up on the unequal capital resources of private households, it is further claimed that poor households have to contribute to financing the return on investment of investors in EEG-supported plants $[10,44]$. However, of course, the participation of poor households in the financing of facilities for generating renewable energy is based on the fact that they also consume the electricity generated by those facilities. It is an economic fact in a market economy that consumers have to pay fees for a service used to the provider of that service, because of course its production did not take place free of charge. So, this flow of payment is not unique to renewable energies either, and instead it is typical of all market services on the above grounds. So far, for good reason, it has rightly not been argued with the same excitement that socially disadvantaged groups have to finance the return on investment of bakery businesses and/or "rich" master bakers. The fact that the returns on renewables (unlike the "returns on bread") are guaranteed and shaped by the state does nothing to change this: if the market does not reflect the true costs of conventional-nuclear electricity generation, the government has to take corrective action for welfare reasons. Anyone who wishes to generate private investment in renewable energies must pay the producers appropriately for providing the electricity. Furthermore, this payment must cover both the investment costs and the operating costs as well as including sufficient returns on the capital provided, otherwise the desired private investment in the generation facilities will not materialise.

When making investment decisions, owners of capital select an investment option that matches their individual preferences from a range of investment options with a corresponding risk-return ratio. If, for reasons carefully considered to benefit the whole of society, flows of capital are to be redirected into facilities for generating renewable energies, then the investment in this option must offer either a higher return for the same risk or the same return for a lower risk than the hitherto best investment option; in other words, it must at least compensate the benefits foregone (the opportunity costs). However, that also means that a true betterment of the capital investors through the EEG only takes place to the extent that the expected value of the return on an RES investment exceeds the investment that would otherwise have been made.

Against this backdrop, the risk-return ratio of the EEG support scheme could admittedly have been set higher than necessary, so that the windfall effects show up on the side of the plant operators, and, as a result, an administered redistribution from the electricity customers to the RES investors does actually take place. The much-criticised problem of excessive promotion of photovoltaics (PV) in the period 2009-2012 suggests that-at least in the area of solar energy production—this was temporarily the case [5]. Policy makers have meanwhile attempted to counter this by regularly adjusting the PV 
feed-in tariff rates. However, concerning this critique, one has to distinguish between the fundamental suitability of the instrument and the political inertia in responding to changing framework conditions. Furthermore, the ongoing reluctance on the part of major investors to invest in the renewables sector suggests that the achievable returns in the area of EEG-supported plants are still too low to cover their opportunity costs. Instead, the incentive system anchored in the EEG means that the transformation of the energy system is also characterised by a changed constellation of actors [45], as opportunities have opened up for wider circles-including consumers who have become producers-to share in the monetary benefits of the supply of energy compared with the previous supply system with its large-scale structures.

The criticism that only "the rich" benefit from the EEG because it leads to payment flows from the consumers (incl. the financially weak) to the producers (who tend to be financially strong), even in principle, falls short of the mark. As already mentioned above, although this observation is certainly accurate and the only possibility in a market economy, it ignores the fact that these payment flows are faced with a counter flow of payment in kind, namely, the supply of electricity in a specific quality that is highly valued by society. In addition, the observation also ignores the fact that the EEG does not only generate costs for the consumers and benefits for the producers. The EEG not only very effectively incentivises investments in renewable energy generation plants, at the same time it also inherently incentivises the supply of public goods. In particular, these include-in addition to securing the supply of energy-climate protection and the avoidance of other environmental risks associated with fossil- and nuclear-based energy supply. All consumers of renewable energies benefit from these public goods, and not just their producers. Also, the price-lowering effect of the EEG-supported plants on the electricity exchange, which is reflected in the final consumer prices in the presence of sufficient competition, is not only affecting the electricity bills of those who cause the effect (RES producers), but the electricity bills of all electricity consumers (cf. e.g., [46]). These examples show: it is impossible to make general statements about the winners and losers of the EEG on the basis of a mere consideration of the direct distributional effects of the EEG surcharge payments and remunerations because, as a partial consideration, it leaves out other essential aspects of the cost and benefit distribution and, in addition, completely masks the complex distributional effects of the relevant alternatives (state promotion of conventional electricity generation, incidence of external costs).

Against this backdrop, scandal-mongering such as the recent dramatic warning about a ticking "socio-political time bomb" [7] has no factual basis. However, unfortunately, such dramatisations also contribute to obscuring the relevant social and political challenges of the electricity transition (see Section 3).

\section{Remaining Distributional Challenges of the RES-Promotion Scheme-Socio-Political Desiderata}

Although the points of criticism put forward in the debate on the distributional policy aspects of the EEG in the form of the theses outlined above are not very plausible, and at any rate give no reason to fundamentally play off climate, environmental and energy policy against distribution and socio-political concerns, the question remains: to what extent must energy transition policy also address the distributional effects of higher energy prices. As Section 2 shows, the promotion of renewables is only partly responsible for the recent increases in the price of electricity. Nevertheless, a significant increase in electricity prices was observed over the last few years and this can lead to affordability problems among poor households. If poor households are not able to respond sufficiently to price increases, it is necessary to determine where the structural causes for this lack of capacity to respond lie, and which countermeasures can be taken to address the problem.

However, in the debate surrounding the social acceptability of the energy transition, the buzzword "fuel poverty" is often used solely in the connotation of an unacceptable cost effect of rising electricity prices and, as explained above, gets mixed up, not very constructively, with the equalisation mechanism of the EEG. Hence, it is claimed that either a deceleration of the expansion of renewables or state 
intervention to correct the electricity price or the design of the surcharge is needed in order to guarantee the social acceptance of the energy transition [47].

However, the various policy proposals for setting socially acceptable electricity prices that have been put forward against this background are far from convincing: it is possible to establish that both the proposals for reducing the German electricity tax and for offering social tariffs have little or no unburdening effect on low-income households and suffer from a high degree of target group inaccuracy [32]. In addition, proposals for a reduction of the electricity tax-while having only low potential to unburden private households-lead to considerable deficits in the public budget (cf. Table 1).

Table 1. Comparison of the effects of different electricity tax reduction proposals on private households and on the federal budget.

\begin{tabular}{|c|c|c|c|}
\hline $\begin{array}{l}\text { Electricity Tax Reduction } \\
\text { Proposal (2012/2013) }\end{array}$ & $\begin{array}{c}\text { Annual Gains for a Private } \\
\text { Household (Average) }\end{array}$ & $\begin{array}{l}\text { Annual Tax Revenue } \\
\text { Losses for the Federal } \\
\text { Budget in EUR }\end{array}$ & $\begin{array}{c}\text { Revenue Losses } \\
\text { As a Percentage of Electricity } \\
\text { Tax Revenues in } 2013\end{array}$ \\
\hline Reduction by $25 \%$ & 18 EUR & 716 million & $11 \%$ \\
\hline Reduction to $0.5 \mathrm{ct} / \mathrm{kWh}$ & 54 EUR & 2.2 billion & $34 \%$ \\
\hline $\begin{array}{l}\text { Reduction to } 0.1 \mathrm{ct} / \mathrm{kWh} \text { for } \\
\text { the first } 500 \mathrm{kWh} \text { consumed }\end{array}$ & 10 EUR & 394 million & $6 \%$ \\
\hline $\begin{array}{l}\text { Reduction to } 0.1 \mathrm{ct} / \mathrm{kWh} \text { for } \\
\text { the first } 1,000 \mathrm{kWh} \text { consumed }\end{array}$ & 20 EUR & 789 million & $12 \%$ \\
\hline
\end{tabular}

Source: [32] (p. 25). Calculation basis: The electricity tax amounted to $2.05 \mathrm{ct} / \mathrm{kWh}$. Average electricity consumption per household was calculated on the basis of the data on final energy consumption in private households for 2011(electricity) [48] and the number of households for 2011 (40.4 million according to the micro-census) at $3455 \mathrm{kWh}$ per annum. According to the Federal Ministry of Finance, the expected electricity tax revenue for 2013 amounted to 6.4 billion euros.

Furthermore, in markets where competition is weak, such as the basic electricity supply market, to what extent decreasing tax rates would affect market prices remains an open question; here, windfall effects appear highly likely [49]. So, corresponding proposals are likely to promise above all political returns and, to that extent, primarily demonstrate vote-maximising political behaviour. Furthermore, given the societal challenge of transforming the energy supply system, socially motivated electricity price reductions also send out the wrong signals and violate the polluter-pays principle. They attempt to address poverty in general, but not the barriers that prevent low-income households from exploiting the relevant electricity savings potential.

Indeed, the burdens and options for action available to vulnerable households in dealing with rising energy prices have to be examined more closely in order to demonstrate in a constructive manner how households and society can cope with increasing costs of energy services. First, as elaborated above in Section 2.1, in principle, it is always possible to respond to rising energy prices by shifting or reducing one's consumption. This course of action is undoubtedly open to all consumers, albeit to varying degrees. Furthermore, in societies organised on the basis of the welfare state model, the state is deemed to have a duty of care to ensure a minimum subsistence level for those who, for one reason or another, cannot achieve this through their own efforts. This means that in cases of rising price levels for basic commodities, the state should react with a corresponding adjustment of transfer eligibility and payments. However, current analyses show that there is a gap in Germany today between the household energy allowances contained in the standard needs defined under social law (electricity and/or gas without heating) and the actual expenditures on electricity among recipients of transfer payments ( $c f$. Figure 3). So, in cases where income poverty is root cause for households no longer being able to respond to rising energy prices by shifting their outgoings on other consumer goods in order to purchase an acceptable level of energy services, the social state is called upon to exercise its duty of care by making corresponding adjustments to transfer payments and the eligibility requirements for transfer payments. An acceptable level of energy services-such as heat, light, use of appliances-can essentially be understood as a minimum standard of room temperature as well as 
a minimum standard in relation to the use of electrical appliances and lighting products typically used for running a household [32]. In Germany, such a general definition of minimum standards for energy services does not exist at the moment.

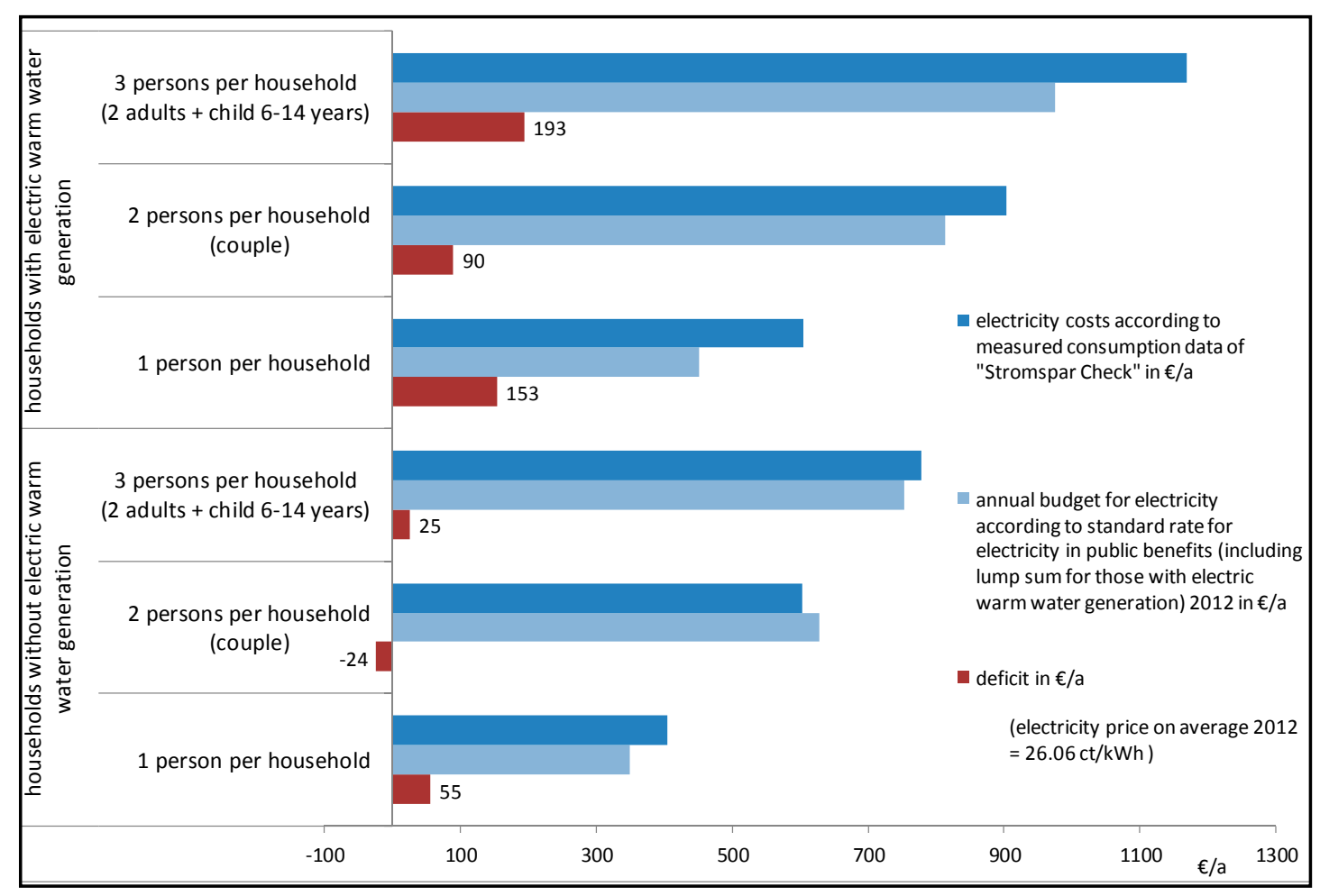

Figure 3. Gap between the standard rate for electricity in social benefits and real costs acc. to consumption data measured by the project "Stromspar-Check" for 2012 ( $N=22,527)$. Source: [32] (p. 21).

However, a mere adjustment of transfer payments to rising energy prices is possibly not cost-efficient when it is not low income alone but high essential consumption quantities for satisfying a basic requirement for energy services (heat, light, cooling) that are responsible for the high energy costs. Here, attempting to combat poverty by loosening the budget constraint would not on its own be sufficient. A glance at the determinants of energy consumption quantities and at the exploitability of energy-saving potential reveals that households differ in terms of their energy consumption, not just due to variables that can, in principle, be influenced, such as to what extent they are equipped with energy-consuming appliances, how efficient those appliances are, and the respective usage pattern. They also differ due to structural variables that are almost impossible for them to influence, such as the type of heating or hot water system installed in rental housing. Energy-saving behaviour can reduce energy costs. However, the greatest energy savings are to be made where savings can only be achieved by making considerable investments, for example by installing a new heating system, instant water heater or refrigerator. Households with a small disposable income, who in Germany live mainly in rented accommodation, are seldom in a position to exploit significant consumption-savings and therewith also cost-savings. In this case, for low-income households, "fuel poverty" becomes a structural energy efficiency problem which they are unable to overcome with their own resources.

Policies that focus exclusively on price equalisation as a remedy for "fuel poverty" run the risk of turning out to be inefficient in the long run because the root causes of high energy costs are not eliminated. As a result, social transfer payments must be made at consistently high and (under the assumption of continuing increases of electricity prices) at ever-increasing levels. This places a permanent burden on public budgets. Instead, a targeted energy efficiency policy could serve as an instrument of social policy that is compatible with the Energiewende, which not only sets priorities 
with regard to the amount of exploitable savings potential but also with regard to the target groups who cannot make efficiency investments based on their own resources or bear the costs of investment and, thus, cannot benefit from the advantages of efficient energy applications [32,47].

Consequently, an energy efficiency policy that simultaneously leads to a cost-efficient reduction of energy consumption could hold the key to a socially acceptable design of the energy transition. However, this applies only insofar as those who spend a larger share of their budget on energy are also the beneficiaries of efficiency policy measures. Though, as analyses of the current energy efficiency policy portfolio demonstrate, the regressive distributional effects of a surcharge-financed energy transition policy are partially reinforced by the fact that low-income households are unintentionally but effectively excluded from exploiting existing efficiency policy measures [32].

\section{Discussion}

The discussion on the distributional effects of energy prices and energy consumption is of course neither new nor a matter of public debate in Germany exclusively. In fact, this debate has a long tradition in the literature and encompasses different aspects of access to and affordability of energy and energy services, respectively. According to Liddell et al., the term "fuel poverty" that is employed in the UK debate to describe energy related affordability problems of poor households is probably the oldest and most established one in this context [50]. Internationally, however, the term "energy poverty" is more common, but is used with different meanings by different authors [51]. What makes the debate we are focusing on in this article particular is that it concentrates on the distributional effects of the promotion of renewables exclusively. However, this discussion on the social acceptability of sustainability-oriented pricing in order to support renewables is not limited to Germany either. For instance, Verde and Pazienza show that the Italian surcharge for renewables support is of regressive character and conclude that the fairness of this mechanism is questionable [52]. Similarly, Nelson et al. analysed the incidence of the residential feed-in tariff scheme for solar power systems in Australia and found that its funding via a surcharge on the electricity price is regressive which could be evaded by replacing the surcharge with a general tax funding [53]. For the US economy, Rausch and Mowers investigated the impacts of clean and renewable energy standards on income distribution. They show that both instruments are regressive as a result of rising energy prices and new investment opportunities for capital owners [54]. Also, Ian Gough states for the UK context that power price increasing policies would be "the most regressive way of curbing energy use" [55] (p. 4 et seq.).

Although, as the above mentioned examples have shown, there is some scientific discussion on the question of social acceptability of renewable policies outside Germany too, it seems that this debate is much livelier in Germany than in other countries and, moreover, is conducted publicly to a greater degree. The reason for that may be found in the marked extension of renewable energies for power supply in Germany during the last decade which has led to a significant increase in the EEG surcharge as one component of the electricity price. Thus, a similarly intense discussion might come up in other countries with ambitious renewable policies that are to be funded via the power price as well. However, compared to the general discussion on fuel poverty, the perspective of this debate is much narrower as it focuses not only merely on electricity prices but even on one particular component of it, leaving aside other causes of electricity affordability problems such as low incomes and lacking energy efficiency. Consequently, the conclusions that are drawn from such a perspective solely take into account electricity price related measures for reducing affordability issues, either state intervention in order to reduce the power price or cutting the promotion of renewables as the alleged cause of rising power prices.

The latter option makes clear that the intensity of the debate that can be observed in Germany has its roots probably not only in actual power price increases but also in the redistribution of economic rents that comes along with the transition of the power supply system as new actors enter into the market. A surprising phalanx of representatives from the economic, scientific and political spheres in Germany have recently expressed their concern about the social acceptability of the 
energy transition and, against this background, are demanding either a change of instrument for the promotion of renewables in the electricity sector and/or a slowing down of the pace of the expansion of renewables $[7,44,56]$. However, concerns about social aspects are only raised very selectively in the process: At any rate, so far, corresponding concerns over the long-standing increase in electricity prices for private households (long before the massive expansion of renewables) have hardly ever been raised before in Germany. What is more, respective concerns-in as much as it is evident-are preferably reserved for the area of electricity supply widely neglecting other energy sectors. In fact, it is precisely in the power sector that energy prices have increased less strongly than for heat and transport which, in addition, play an even greater role in the household budget of consumers and similarly exhibit state influence (e.g., through energy taxes). Other drivers for electricity prices, such as problems related to market power, industry privileges in relation to the EEG surcharge, or the potential electricity price effects of capacity mechanisms as well as the hidden distributional effects caused by public budgets or external costs, have rarely been presented as problematic or discussed with such verve. The scientific advisory board at the German Federal Ministry for Economic Affairs and Energy, for example, bemoans the "distributional effects" of the promotion of solar power [43], but not those related to the socialisation of nuclear risks or climate change. Furthermore, in this context even some of the most vehement advocates of market-based solutions carelessly overlook the standard economic argument that social issues should be regulated by income and social policy and not by the price of specific goods. Last but not least, such socio-political arguments that are directed against the growing importance of renewable energies and a greater diversification of the producer structure in the energy sector help to conceal (strategic) income interests of relevant players in the field.

Against this backdrop, it once more becomes clear that evidence-based research is needed that investigates whether the power price funded support of renewables really leads to a significant increase in affordability problems (see e.g., for the German case [24,27]). The mere insight that power prices have a regressive impact (which in fact is the case for all goods to cover basic needs) is neither new nor does it automatically implicate that increasing power prices (e.g., as a result of renewables support) do lead to serious electricity affordability problems.

\section{Final Conclusions}

In Germany, there has been a very lively debate about the social acceptability of the promotion of renewables via a surcharge on the electricity price. However, as our analysis shows, the increase in German electricity prices during recent years has only partly been caused by the promotion of renewables. Moreover, if market-based environmental and climate policy is to take place, then the prices must reflect the true cost and also include the external costs of the consumption of goods, as externalities describe the burdens imposed on third parties by one's own consumption. Therefore, as long as electricity prices do not tell the whole economic and ecological truth, it is impossible to conduct a fairness evaluation on the basis of market electricity prices alone-especially since additional distributional effects (caused, for instance, by public budgets) would also have to be taken into consideration.

The potential affordability problems of environmental and climate policy based on the polluter-pays principle must nevertheless be carefully identified and adequately addressed in the context of sustainability policy: specific instruments of social as well as environmental and climate policy should be carefully selected for this purpose in order to intervene appropriately, especially because they are associated with new distributional impacts. However, socio-politically motivated interventions in consumer prices are not advised: environmental and climate targets and social acceptability should not be played off against one another. The role of resource efficiency and resource saving to reduce the tension between the sustainability targets, on the other hand, should receive greater recognition. Simply reducing individual distributional, and especially electricity affordability problems, to the cause "promotion of renewable energies"—an argument sometimes encountered in 
the current discussion about the energy transition but for which there is little empirical evidence-is in any case not scientifically convincing.

Therefore, however much sustainability policy must at all times consider and balance out target conflicts between social, ecological and economic issues, social concerns give little cause to fundamentally question the promotion of renewable energies. Sustainability policy that consistently focusses on responsibility in the use of resources is not unjust per se. Nevertheless, with a view to vertical equity between social groups, there are still gaps in the justification with respect to consumers' ability to pay. Our analysis shows that such problems in the area of sustainable transformation of energy systems can be addressed through a mix of measures in the field of social policy and a targeted energy efficiency policy; direct, socially motivated price interventions (in this case in the electricity price), on the other hand, should be excluded so that prices can assume their incentivising and signal function, thus addressing economic as well as ecological sustainability.

Acknowledgments: The authors appreciate comments on drafts of this article by 2 anonymous peer reviewers. Moreover, the authors would like to thank the Helmholtz Alliance "ENERGY-TRANS" for funding this research.

Author Contributions: All authors wrote this article together and read and approved the final manuscript.

Conflicts of Interest: The authors declare no conflict of interest.

\section{References}

1. United Nations. Transforming Our World: The 2030 Agenda for Sustainable Development. Available online: https://sustainabledevelopment.un.org/content/documents/7891Transforming\%20Our\%20World.pdf (accessed on 28 September 2015).

2. Gawel, E. Zur Gerechtigkeit von Umweltabgaben. Steuergleichheit und Leistungsfähigkeitsorientierung als Probleme von Ökosteuern. Z. Wirtsch. 2000, 2, 182-211.

3. Heindl, P.; Löschel, A. Addressing Social Implications of Green Growth. In Proceedings of the Green Growth and Sustainable Development Forum. Session 1: Energy Sector Reform and Its Impact on Households, Paris, France, 13-14 November 2014.

4. Organisation for Economic Co-operation and Development (OECD). Managing Water for All: An OECD Perspective on Pricing and Financing; OECD: Paris, France, 2009.

5. Bardt, H.; Niehus, J. Distribution Effects of the Renewable Energies Act. Z. Energiewirtsch. 2013, 37, $211-218$. [CrossRef]

6. BMWi; BMU. Energiekonzept für eine Umweltschonende, Zuverlässige und Bezahlbare Stromversorgung. Available online: http://www.bundesregierung.de/ContentArchiv/DE/Archiv17/_Anlagen/2012/02/ energiekonzept-final.pdf?_blob=publicationFile\&v=5 (accessed on 24 September 2015).

7. Frondel, M.; Sommer, S. Energiekostenbelastung Privater Haushalte: Das EEG als Sozialpolitische Zeitbomb?; RWI-Materialien: Essen, Germany, 2014.

8. Initiative Neue Soziale Marktwirtschaft (INSM). Das EEG Belastet Vor Allem Geringverdiener. Available online: http://insm.de/insm/dms/insm/text/presse/pressemeldungen/2012/pressemeldung-EEG-studie/ Pressemeldung\%20EEG-Studie.pdf (accessed on 9 January 2015).

9. Institut der Deutschen Wirtschaft Köln (IW). Geringverdiener Zahlen Die Zeche; IW: Köln, Germany, 2012; pp. 1-2.

10. Vassiliadis, M. Energiewende mit Mehr Weitblick; Handelsblatt of 22 July 2013: Düsseldorf, Germany, 2013.

11. Mayer, J.N.; Burger, B. Kurzstudie zur Historischen Entwicklung der EEG-Umlage; Fraunhofer ISE: Freiburg, Germany, 2014.

12. BMWi. EEG-Umlage in Cent pro Kilowattstunde. Available online: http://www.bmwi.de/DE/Themen/ Energie/Erneuerbare-Energien/eeg-2014,did=663076.html (accessed on 3 September 2015).

13. Küchler, S. Kostenverteilung in der Energiewende und Strompreisprivilegien der Industrie. In Proceedings of the Workshop Sozial Gerechte Energiewende, Berlin, Germany, 26 November 2012.

14. Rosenkranz, G.; Quentin, J.; Litz, P. Energiewende oder Energiewendeende: Warum der Ausgang der Bundestagswahl über den Erfolg der Energiewende Entscheidet; Deutsche Umwelthilfe: Berlin, Germany, 2013. 
15. BMWi. Zahlen und Fakten Energiedaten: Nationale und internationale Entwicklung. Available online: http:/ / bmwi.de/BMWi/Redaktion/Binaer/energie-daten-gesamt,property=blob,bereich=bmwi2012, sprache $=$ de,rwb=true.xls (accessed on 8 September 2015).

16. Agentur für Erneuerbare Energien. Entwicklung der Monatlichen Energiekosten eines Drei-Personen-Musterhaushalts. Available online: http://www.unendlich-viel-energie.de/media/image/ 4087.AEE_Entwicklung_Energiekosten_Musterhaushalt_nov13_72dpi.jpg (accessed on 19 November 2015).

17. Bundesverband Erneuerbare Energien (BEE). Hintergrundpapier zur EEG-Umlage 2014; BEE: Berlin, Germany, 2013.

18. Sensfuß, F. Analysen zum Merit-Order Effekt Erneuerbarer Energien. Update für das Jahr 2010; Fraunhofer ISI: Karlsruhe, Germany, 2011.

19. Erdmann, G. Kosten des Ausbaus der Erneuerbaren Energien; Studie der Technischen Universität Berlin; Im Auftrag der Vereinigung der Bayrischen Wirtschaft (VBW): Berlin, Germany, 2011.

20. Fürsch, M.; Malischek, R.; Lindenberger, D. Der Merit-Order-Effekt der Erneuerbaren Energien-Analyse der Kurzen und Langen Frist; EWI Working Paper; EWI: Köln, Germany, 2012.

21. BMWi. EEG in Zahlen: Vergütungen, Differenzkosten und EEG-Umlage 2000 bis 2015. Available online: http:/ / www.erneuerbare-energien.de/EE/Redaktion/DE/Downloads/eeg-in-zahlen-pdf.pdf?_blob= publicationFile\&v=4 (accessed on 8 September 2015).

22. Reuster, L.; Küchler, S. Industriebegünstigungen bei der EEG-Umlage und deren Auswirkung auf die Restlichen Stromverbraucher; FOES: Berlin, Germany, 2012.

23. Musgrave, R.A.; Musgrave, P.B. Public Finance in Theory and Practice, 5th ed.; McGraw-Hill: New York, NY, USA, 1989.

24. Neuhoff, K.; Bach, S.; Diekmann, J.; Beznoska, M.; El-Laboudy, T. Distributional Effects of Energy Transition: Impacts of Renewable Electricity Support in Germany. Econ. Energy Environ. Policy 2013, 1, 41-54. [CrossRef]

25. Grösche, P.; Schröder, C. On the redistributive effects of Germany's feed-in tariff. Empir. Econ. 2014, 4, 1339-1383. [CrossRef]

26. Heindl, P.; Schüßler, R.; Löschel, A. The German Energy Transition from the Perspective of Social Justice. Wirtschaftsdienst 2014, 7, 508-514. [CrossRef]

27. Gawel, E.; Geißler, H.; Lehmann, P. Beeinträchtigt die Förderung erneuerbarer Energien die Erschwinglichkeit der Stromversorgung? Eine empirische Untersuchung für Deutschland. In Energie und Soziale Ungleichheit: Zur Gesellschaftlichen Dimension der Energiewende in Deutschland und Europa; Großmann, K., Schaffrin, A., Eds.; Springer: Berlin, Germany, 2015.

28. Heindl, P. Ökonomische Aspekte der Lastenverteilung in der Umweltpolitik am Beispiel Energiewende. Ein Beitrag zum Interdisziplinären Dialog; ZEW Discussion Paper; ZEW: Mannheim, Germany, 2014.

29. Energy Brainpool. Zusammenhang von Strombörsenpreisen und Endkundenpreisen; Study on Behalf of Agora Energiewende; Energy Brainpool: Berlin, Germany, 2013.

30. Bürger, V. Quantifizierung und Systematisierung der technischen und verhaltensbedingten Stromeinsparpotenziale der deutschen Privathaushalte. Z. Energiewirtsch. 2010, 34, 47-59. [CrossRef]

31. Tews, K. Stromeffizienztarife für Verbraucher in Deutschland? Vom Sinn, der Machbarkeit und den Alternativen einer Progressiven Tarifsteuerung; FFU-Report 05-2011; FFU: Berlin, Germany, 2011.

32. Tews, K. Energiearmut definieren, identifizieren und bekämpfen-Eine Herausforderung der sozialverträglichen Gestaltung der Energiewende-Vorschlag für eine Problemdefinition und Diskussion des Maßnahmenportfolios; FFU-Report 04-2013; FFU: Berlin, Germany, 2013.

33. Gawel, E.; Korte, K. Distributional Effects of the Renewable Energies Act: The criticism focuses on the wrong issues. Wirtschaftsdienst 2012, 8, 312-315.

34. Gawel, E.; Korte, K. Verteilungswirkungen des EEG: Wird die Energiewende ungerecht organisiert? Z. Umweltr. (ZUR) 2012, 9, 457-458.

35. Christian Democratic Union of Germany (CDU); Christian Social Union in Bavaria (CSU). Deutschlands Zukunft Gestalten. Coalition Agreement between CDU, CSU and SPD; CDU: Berlin, Germany, 2013.

36. Küchler, S.; Meyer, B. Was Strom Wirklich Kostet. Vergleich der Staatlichen Förderungen und Gesamtgesellschaftlichen Kosten von Konventionellen und Erneuerbaren Energien; FOES: Berlin, Germany, 2012.

37. Manssen, G. Die Zukunft der EEG-Umlage-Weiter auf verfassungswidrigen Wegen? Energiewirtsch. Tagesfr. $2012,11,49-51$. 
38. Gesamtverband Textil + Mode. Eckpunkte für eine Fair Finanzierte Energiewende. Available online: http:/ / www.markenverband.de/presse/pm/PM\%20-Wirtschaftsbuendnis $\% 20$ fordert $\% 20$ faire $\% 20$ Lastenverteilung/pmanlageeckpunktepapier (accessed on 24 September 2015).

39. Verbraucherzentrale Bundesverband (VZBV). Energiewende: VZBV fordert Entlastung für Verbraucher. Available online: http://www.vzbv.de/pressemitteilung/energiewende-vzbv-fordert-entlastung-fuerverbraucher (accessed on 24 September 2015).

40. Gawel, E. EEG-Umlage: Auch weiterhin keine verfassungswidrige Finanzierungs-Sonderabgabe. Energiewirtsch. Tagesfr. 2013, 4, 25-30.

41. Gawel, E. Die EEG-Umlage: Preisregelung oder Sonderabgabe. Deutsch. Verwalt. 2013, 7, 409-417.

42. Gawel, E.; Korte, K. Regionale Verteilungswirkungen und Finanzierungsverantwortung: Bund und Länder bei der Strom-Energiewende. In Energiewende im Föderalismus; Müller, T., Kahl, H., Eds.; Nomos: Baden-Baden, Germany, 2015; pp. 143-184.

43. BMWi. Zur Novelle des Erneuerbaren-Energien-Gesetzes. In Open Letter of the Scientific Advisory Board at the Federal Ministry for Economic Affairs and Technology to the Federal Minister for Economic Affairs (retd.); Rainer Brüderle: Berlin, Germany, 2011.

44. Wetzel, D. Der große Schwindel mit der Solarenergie. Available online: http://www.welt.de/104445672 (accessed on 9 January 2015).

45. Trend:research; Leuphana Universität Lüneburg. Definition und Marktanalyse von Bürgerenergie in Deutschland; Leuphana Universität Lüneburg: Lüneburg, Germany, 2013.

46. Sorge, N.V. Warum es keinen neuen Strompreis-Schock geben wird. Available online: http:/ /www.manager-magazin.de/unternehmen/energie/analyse-warum-strompreise-trotz-hoeherer-eegumlage-kaum-steigen-a-931919.html (accessed on 9 January 2015).

47. Tews, K. Fuel Poverty in Germany: From a Buzzword to a Definition. GAIA 2014, 1, 14-18. [CrossRef]

48. DIW; EEFA. Auswertungstabellen zur Energiebilanz Deutschland 1990 bis 2013. Available online: https: / / www.google.de/url?sa=t\&rct=j\&q=\&esrc=s\&source=web\&cd=3\&ved=0CC0QFjACahUKEwi8kNDT 8ZHIAhWBghoKHZFvCtU\&url=http\%3A\%2F\%2Fwww.ag-energiebilanzen.de\%2Findex.php\%3Farticle_id\% 3D29\%26fileName\%3Dausw_10092014ov.pdf\&usg=AFQjCNFjnSy1DZOa4cA0qK3xTtW5gROKpw\&cad=rja (accessed on 25 September 2015).

49. Gawel, E.; Korte, K. Sozialverträglichkeit als Herausforderung der Energiepolitik—Die ökonomische Sicht. In Proceedings of the Berliner Energietage 2013 (Berlin Energy Days 2013), Berlin, Germany, 15-17 May 2013.

50. Liddell, C.; Morris, C.; McKenzie, P.; Rae, G. Defining Fuel Poverty in Northern Ireland. A Preliminary Review; Ulster: Northern Ireland, UK, 2011.

51. Li, K.; Lloyd, B.; Liang, X.J.; Wie, Y.M. Energy poor or fuel poor: What are the differences? Energy Policy 2012, 68, 476-481. [CrossRef]

52. Verde, S.F.; Pazienza, M.G. Cost Recovery of RES-E Support in Italy: A New Case for a Carbon Tax; EUI Working Papers RSCAS 2103/72; European University Institute: Florence, Italy, 2013.

53. Nelson, T.; Simshauser, P.; Kelley, S. Australian Residential Solar Feed-in Tariffs: Industry Stimulus or Regressive form of Taxation? Econ. Anal. Policy 2011, 41, 113-129. [CrossRef]

54. Rausch, S.; Mowers, M. Distributional and efficiency impacts of clean and renewable energy standards for electricity. Resour. Energy Econ. 2014, 36, 556-585. [CrossRef]

55. Gough, I. The Challenge of Climate Change for Social Policy. Available online: http://eprints.lse.ac.uk/ 51146/1/_Libfile_repository_Content_Gough\%2C\%20I_Gough_challenge_climate_\%20change_Gough_ challenge_climate_\%20change_2013.pdf (accessed on 12 November 2015).

56. Bardt, H.; Niehues, J.; Techert, H. Das Erneuerbare-Energien-Gesetz-Erfahrungen und Ausblick; Initiative Neue Soziale Marktwirtschaft: Cologne, Germany, 2013.

(C) 2015 by the authors; licensee MDPI, Basel, Switzerland. This article is an open access article distributed under the terms and conditions of the Creative Commons by Attribution (CC-BY) license (http:/ / creativecommons.org/licenses/by/4.0/). 